\title{
SCANNING ELECTRON MICROSCOPY OF THE CONTACT SITE OF CONIDIA AND TRICHOGYNES IN CLADONIA FURCATA
}

\author{
Rosmarie HONEGGER *
}

\begin{abstract}
The contact sites of pycnidia and the terminal cells of trichogynes in Cladonia furcata were investigated using either freshly fixed material, or ascomatal primordia and pycnidia from which the gelatinous material either on the primordial surface, or in the pycnidial cavity, had been removed. The sickle-shaped conidia fused, tip first, with the cell wall of trichogynes. Circular holes of about the diameter of the conidia found in the cell walls of trichogynes arise from enzymatic degradation of the wall material by fusing conidia. As the conidia appear to stick on any gelatinous surface material of the thallus the adhesion process is presumed to be unspecific.
\end{abstract}

\section{Introduction}

The dikaryotization process at the beginning of the generative reproductive cycle is among the least understood aspects in lichenology. Trichogamy, the fusion of a spermatial conidium with the trichogyne of the ascogone was supposed to occur in those members of the Lecanorales and in a few non-lecanoralean species where 'pycnoconidia' had been observed adhering to the terminal cells of protruding trichogynes (Stahl 1877, Baur 1898, Nienburg 1908, Stevens 1941, Johnson 1954, Henssen 1963, Ahmadjian 1966, Jahns 1970, Honegger 1978). However, in none of these studies were the karyological aspects investigated. Jahns (1970) observed binucleate cells in the basal cells of a trichogyne in Cladonia chlorophaea whose terminal cells had died and contained no nuclei. Based on his observations on the surprisingly great range of variation in growth form and pigmentation in a large series of monospore cultures of the mycobiont of Cladonia cristatella, Ahmadjian (1964) concluded that a sexual process and thus the recombination of genes might have occurred. Moreau \& Moreau $(1928,1932)$, on the other hand, supposed trichogynes and pycnoconidia to be rudimentary and functionless with regard to the dikaryotization process, and apomixy to be the rule in lichenized ascomycetes. Their hypothesis was mainly based on histological investigations on ascomatal ontogeny and the detection of bi- and even multinucleate ascogonial cells without functional trichogynes. Due to the uncertainty about the function of the tiny pycnoconidia the formerly frequently used term spermatium (e.g. Tulasne 1852, Lindsay 1861, 1872, Glück 1899, Johnson 1954) has been replaced by ' microconidium ' in some more recent lichenological literature (e.g. Letrouit-Galinou 1973, Henssen \& Jahns 1973, Hale 1974).

In the present note some observations on the early stages of ascomatal development in Cladonia furcata (Huds.) Schrader var. furcata are reported. The ontogeny of the ascomata of this taxon has been investigated by Wolff (1905) and Jahns

^Cytology Department, Institute of Plant Biology, University of Zürich, Zollikerstrasse 107, CH-8008 Zürich, Switzerland. 

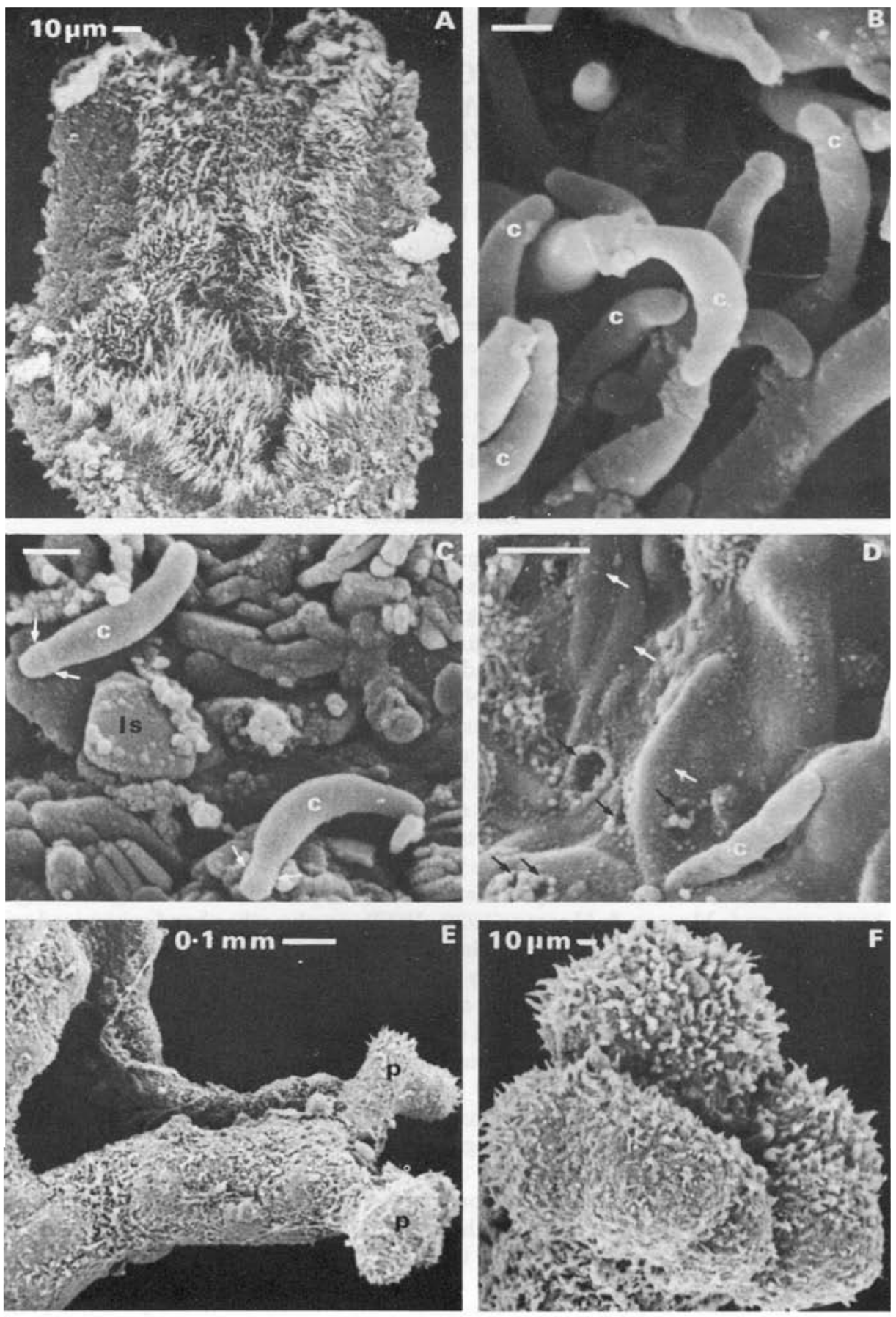
\& Beltman (1973). The correlations between environmental factors and developmental stages of the ascomata have also been studied over a long period by Jahns et al. (1978). Six developmental stages of ascoma formation were distinguished (Jahns et al. 1978), starting with pale branch tips (stage 1), through enlarged, pigmented branch tips (stage 3) to mature fruit bodies (stage 6). The SEM micrographs presented here are concerned with stage 4 of Jahns et al. (1978) in which ascomatal primordia are visible under a dissecting microscope as swollen, pigmented structures with a fine, pruina-like surface layer formed by protruding terminal cells of the trichogynes. Jahns $(1970,1973)$ pointed out that the delicate trichogynes are short-lived structures which only develop, as demonstrated in Cladonia furcata var. furcata (Jahns et al., 1978), under particular climatic conditions during a short period of the year.

\section{Materials and Methods}

Cladonia furcata (Huds.) Schrader var. furcata was collected at the end of March 1983 after several weeks of cold and rainy weather in the Forett de Huelgoat in central Brittany, France. All thalli of the population were fertile, but the developmental stages of the ascomata were not synchronized.

\section{Scanning Electron Microscopy (SEM)}

(1) Primordia of freshly collected ascomata were fixed in $1.25 \%$ glutaraldehyde and $1.5 \%$ acrolein in $1 / 30 \mathrm{M}$ phosphate buffer, $\mathrm{pH} 7 \cdot 1$, for $2 \mathrm{~h}$ at room temperature, and postfixed in buffered $2 \%$ osmium tetroxide at room temperature overnight.

(2) Primordia of ascomata and pycnidia which had been sectioned longitudinally in two halves were incubated in a $5 \%$ solution of the commercially available protease-containing washing powder 'Ariel' (Procter \& Gamble Ltd) for $15 \mathrm{~h}$ at $38^{\circ} \mathrm{C}$ to dissolve the mucilaginous material from either the primordial surface or the pycnidial cavity. This simple and efficient method was adapted from Anglesea $e t$ al. (1982). After six water washings, each of $10 \mathrm{~min}$, the material was fixed and postfixed as in (1).

(1) and (2) were dehydrated in acetone, critical point dried, mounted on specimen stubs, sputtered with $80 \%$ gold and $20 \%$ palladium, and examined in a Cambridge Stereoscan.

\section{Results}

Three different periods within developmental stage 4 of Jahns et al. (1978) were seen in the SEM preparations of ascomatal primordia of Cladonia furcata (Fig. 2). First, the growth phase of the trichogynes which appear above the primordial surface as elongated, hair-like cells (Fig. 2B). Secondly, the secretion of a mucilaginous material which covers the primordial surface and glues groups of trichogynes together in pyramidal tufts (Figs $2 \mathrm{C}-\mathrm{D}, 3 \mathrm{~A}-\mathrm{C}$ ). Masses of fusiform conidia were seen lying on the mucilaginous surface material (Figs $2 \mathrm{D}, 3 \mathrm{~A}-\mathrm{B}$ ). Some of

FIG. 1. SEM preparations of pycnidium (conidioma), conidia and ascomatal primordia in Cladonia furcata. A, Median longitudinal section of a pycnidium after dissolution of the mucilaginous matrix of the pycnidial cavity, $\times 340$. B, Detail of A, showing the inner surface of the pycnidium with phialidic condiogenous cells bearing fusiform conidia (c) $\times 7900$. C, outer surface of the pycnidium with adhering conidia (c) and crystalline lichen substances (ls); arrows point to the weakly visible terminal ring-like bulge of the conidia, $\times 7250$. D, Surface of the cortical layer of a lateral branchlet which bears a pycnidium at its tip; a conidium (c) is lying on the surface, several others (white arrows) were sinking into the gelatinous matrix of the cortex; black arrows point to circular holes in the gelatinous matrix which were formed by adhering conidia and/or bacteria, $\times 7480$. E, Two groups of ascomatal primordia ( $p$ ) inserted terminally at a short lateral branchlet; the lateral slit of the main axis of the fruticose thallus is continuous with the lateral branchlet, $\times 70$. F, Group of primordia of ascomata with protruding trichogynes, $\times 225$. Note: the scale bar unless otherwise stated, equals $1 \mu \mathrm{m}$. 

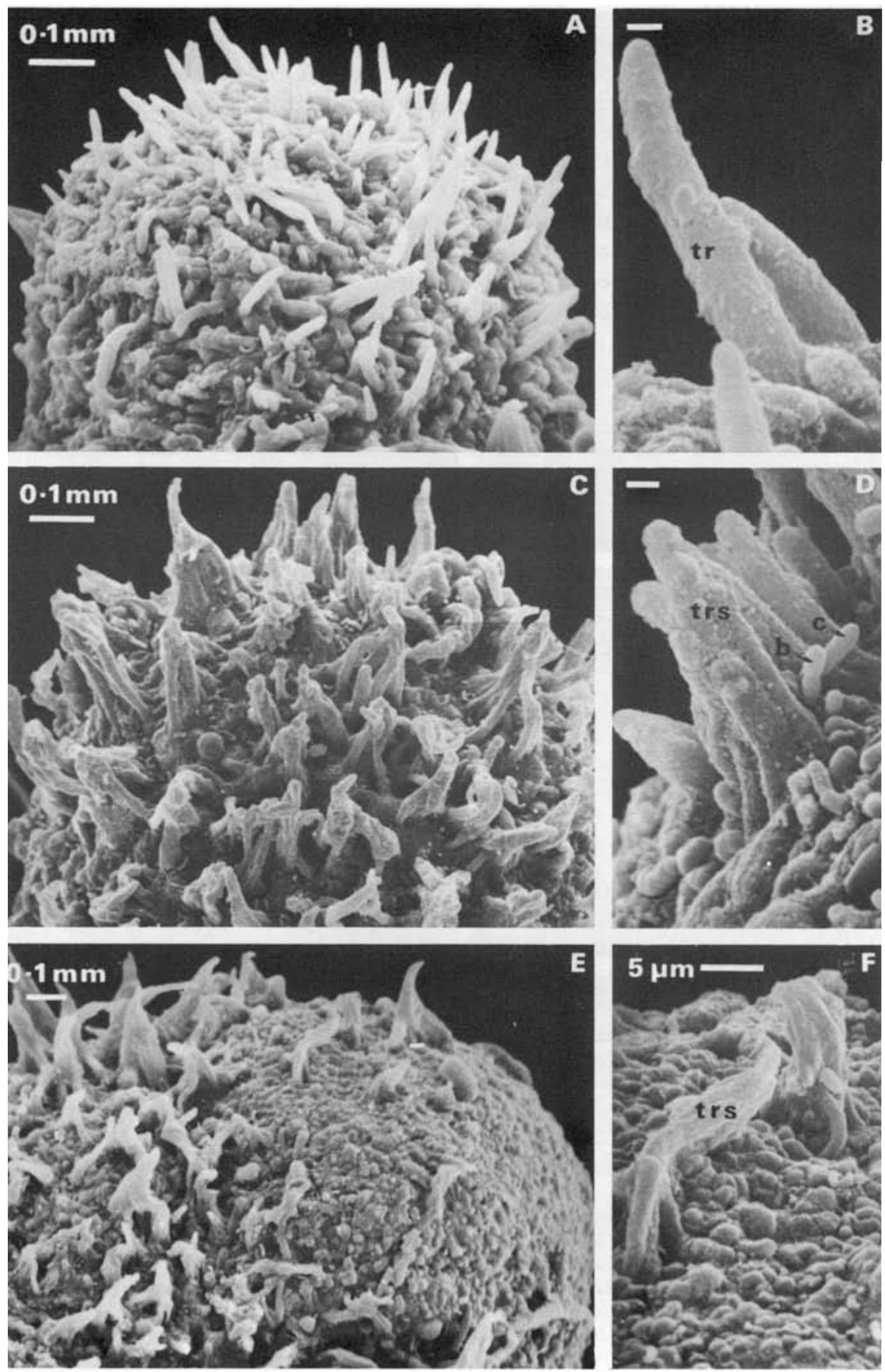
the conidia appeared to be adhering to trichogynes, others were sinking into the mucilaginous matrix at the basis of the trichogynes (Figs 2D, 3B), but the majority did not have any distinct contact with particular cells. Thirdly, the collapse of the tufts of trichogynes at the onset of ascomatal growth and differentiation (Figs 2E-F).

Fusiform conidia were found not only on ascomatal primordia (Figs 2D, 3A-B) and around the pycnidial ostiole (Fig. 1C), but also on the cortex of the otherwise undifferentiated vegetation branches underneath the pycnidia (Fig. 1D) where they sink into the gelatinous material secreted by the cortical hyphae. Most interesting are small circular holes in the gelatinous material of the cortex, some of which were formed by bacteria, others by conidia which were sticking with their tips in this gelatine.

To find out whether there is closer relationship between some of the conidia and trichogynes the uppermost part of the mucilaginous surface material was removed by incubation in a solution of washing powder (see Methods). With the removal of the mucilaginous surface material the majority of conidia disappeared (Fig. 3C). Remaining were a fibrillar component of the surface layer of unknown chemical composition (Fig. 3C) and few conidia, most of which were in contact with trichogynes at their tips (Figs 3D-F). In all of the contact sites investigated the cytological tip of the conidium was the part in contact with the cell wall of the trichogyne, whereas the outline of the terminal ring bulge could be seen on the opposite end (Fig. 3D-E). In contrast to the freshly seceded conidia in or on the pycnidium which reveal a pointed tip (Figs $1 \mathrm{~B}-\mathrm{C}$ ), the conidia in close contact with trichogynes were slightly swollen, somewhat shorter and with a rounded tip (Figs 3D-E). At the contact site a small circular bulge was evident in the uppermost cell wall layer of the trichogyne around the conidial tip (Fig. 3E). Circular holes of about the same diameter as a conidium bordered by a small circular swollen area were seen in the cell wall of many of the trichogynes investigated after dissolution of the mucilaginous surface layer of the primordia (Figs $3 F-G$ ). There is a very high probability that these holes had been formed by adhering conidia through the release of hydrolytic enzymes at their tip.

The majority of the conidia in the act of fusing with the terminal cells of trichogynes were found to be at the bases of the protruding cell of the trichogyne which was formerly covered by mucilaginous material. No fusing conidia were detected at the very tip of the trichogynes. Further, more than one conidium was very frequently found to be in close contact with a single trichogyne (Fig. 3F).

\section{Discussion}

It is not known how the fusiform conidia are transported from the pycnidia, where they were seceded from phialidic condiogenous cells (Fig. 1B; Vobis 1980,

FIG. 2. SEM preparations of three subsequent developmental stages of the trichogynes in Cadonia furcata. A-B, Growth phase; terminal cells of trichogynes (tr) are rising above the primordial surface; some are fully elongated, while others are still growing, $\mathrm{A} \times 840, \mathrm{~B} \times 4040$. C-D, Fully developed trichogynes; the terminal cells of groups of trichogynes (trs) are fastened together by a mucilaginous matrix which covers the entire primordial surface; masses of conidia (c) and few bacteria (b) are lying on the mucilaginous surface layer, $\mathrm{C} \times 820, \mathrm{D} \times 3960$. D-E, Collapsing of the groups of trichogynes (trs) at the beginning of ascomatal development $\mathrm{C} \times 530, \mathrm{D} \times 1600$. Note: the scale bar unless otherwise stated, equals $1 \mu \mathrm{m}$. 

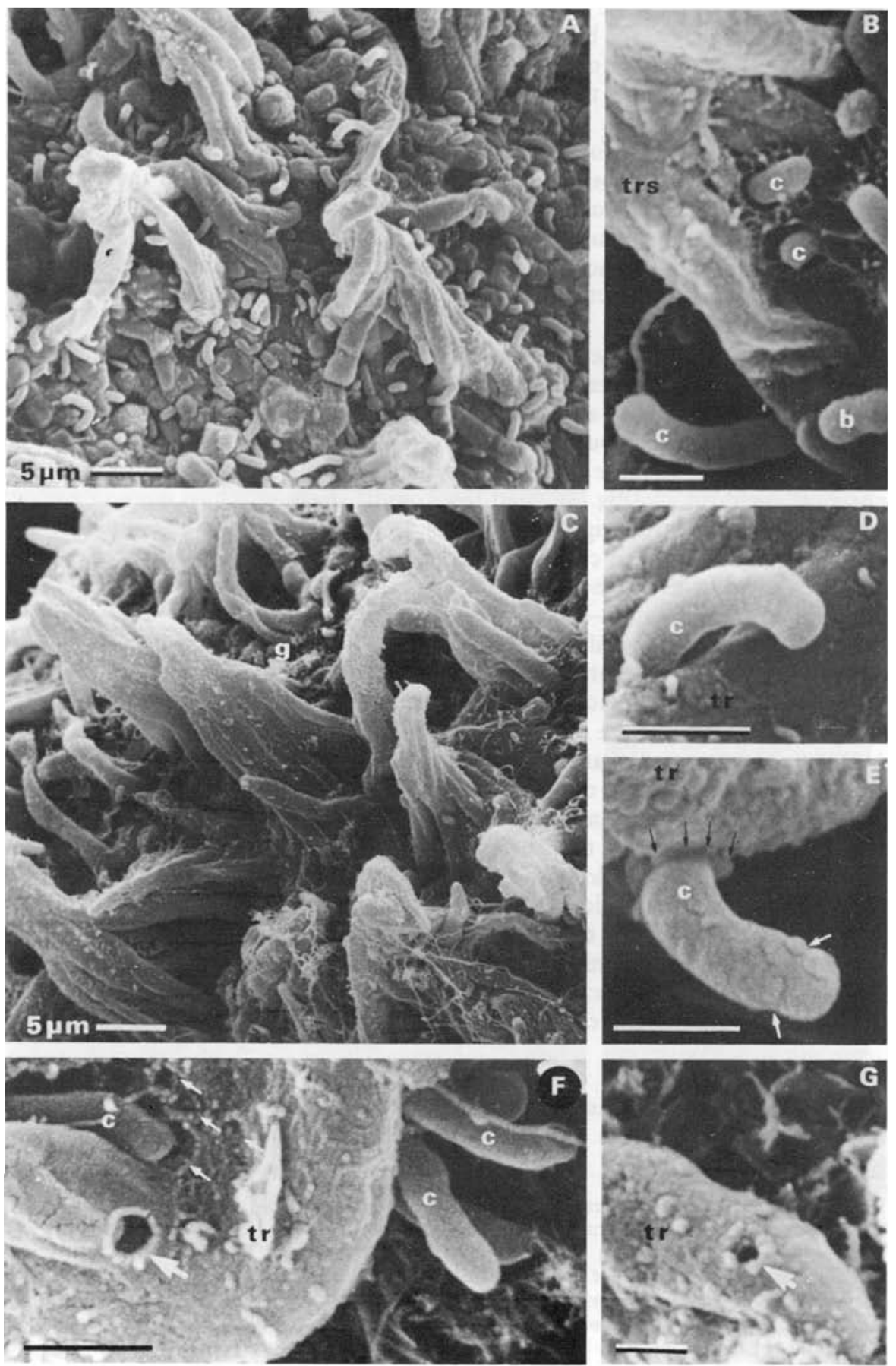
Honegger 1984), to the surface of ascomatal primordia. It is very probable that rain drops act as the vector. In addition the insertion of the primordia onto short lateral branchlets and the complex thallus morphology, mainly the system of lateral slits in the main axis and lateral branchlets, seem to play a rôle in conidium dispersal. As stated by Jahns et al. (1978), pycnidia may be found throughout the year, but it seems that the conidiogenous cells are active only for a rather short period and then pass into a state of senescence and degradation (Honegger 1984). A great number of pycnidia investigated in the present study on Cladonia furcata were 'weeping', i.e. extruding a pale mass of conidia embedded in a mucilaginous material through the ostiole. This weeping is a passive process resulting from the swelling of the mucilaginous, highly hydrophilic contents of the pycnidial cavity. Drops comprising thousands of conidia are very easily wetted and immediately dispersed in a water drop. Raindrops falling on extruding pycnidia might wash and splash the conidial mass down from the ostiole onto the main axis, or even onto a neighbouring thallus in a dense population, and along the system of lateral slits to the ascomatal primordia at the end of short lateral branchlets (Fig. 1E). Obviously, conidial adhesion is a highly unspecific feature since conidia adhere to any gelatinous surface of the thallus. It seems, however, that the primordial surface with its clusters of protruding trichogynes and the gelatinous surface layer is particularly well suited to encourage a great number of conidia to adhere. Fusion, however, seems to be restricted to the trichogynes whose cell wall structure and composition are unfortunately completely unknown.

The present observation does not contribute to our understanding of the karyological aspects of the initial stages of the generative reproduction cycle in Cladonia furcata. The data on the contact sites of conidia and the terminal cell of trichogynes can, however, be interpreted with reference to spermatial function and trichogamy. The conidia of Cladonia furcata were not investigated for their ability to germinate under axenic conditions. In three other Cladonia species, as well as in 10 further lecanoralean species, the conidia did not germinate in culture (Ahmadjian 1969, Vobis 1977). Only in three non-lecanoralean mycobionts has conidium germination so far been demonstrated (Vobis 1977). In at least one of these three non-lecanoralean species, Lecanactis abietina (Ach.) Körber, thickwalled large macroconidia were investigated; these had been termed 'stylospores'

FIG. 3. SEM preparations of the surface of ascomatal primordia with protruding trichogynes and adhering conidia prior to $(A, B)$ and after $(C-G)$ dissolution of the mucilaginous matrix. A, Groups of trichogynes and masses of fusiform conidia, some seemingly adhering to trichogynes, others lying on the mucilaginous matrix, $\times 1830 . \mathrm{B}$, Bases of a group of trichogynes (trs) with adhering conidia (c) some of which are sinking into the mucilaginous matrix, and two bacterial cells (b), $\times 11000 . \mathrm{C}$, Groups of trichogynes after removal of the mucilaginous matrix; the majority of the conidia have been removed but some of those remaining are depicted in D-G, $\times 1820 . \mathrm{D}-\mathrm{E}$, Conidia (c) in close contact with the wall suface of terminal cells of trichogynes (tr), adhering by their apical ends; white arrows point to the weakly visible terminal ring-like bulge, black arrows to a ring-like bulge in the uppermost cell wall layer of the trichogyne around the tip of the fusing conidium, $\mathrm{D} \times 17550 . \mathrm{E} \times 17750$. F, Conidia (c) in contact with the basal part of a terminal cell of a trichogyne (tr); around the tip of the conidium in the left upper half is a fine ring bulge visible in the uppermost wall layer of the trichogyne, and similar circular structures resulting from formerly adhering conidia are seen nearby (small white arrows); a circular hole of about the diameter of a conidium is seen in the cell wall of the trichogyne (large white arrow), $\times 17000 . \mathrm{G}$, Circular hole bordered by a fine ring bulge in the cell wall near the tip of a trichogyne (tr), $\times 9650$. Note: the scale bar unless otherwise stated, equals $1 \mu \mathrm{m}$. 
by Lindsay (1872) who was the first to describe the occurrence of microconidia ('spermatia') in fertile, and macroconidia in sterile thalli of this lichen. Spermatial function and an ability to germinate are not necessarily exclusive properties as has been demonstrated in some non-lichenized ascomycetes. In Neurospora both macro- and microconidia can either act as spermatia, or germinate and form new mycelia (Dodge 1932, Backus 1939, Esser \& Kuenen 1967). The majority of microconidia with a spermatial function so far investigated in the non-lichenized Ascomycotina and also in rust fungi did, however, not germinate (reviewed by Esser \& Kuenen 1967, Littlefield \& Heath 1979). The data on dikaryotization in non-lichenized ascomycetes clearly demonstrates that many different modes of dikaryotization may occur even within a single family (e.g. the Sordariaceae; see Esser \& Kuenen 1967), and that no generalizations should be made on the basis of the study of single or few species. Similar conditions have to be expected in lichen-forming fungi.

Further investigations, mainly cultural experiments and ultrastructural studies, are needed to elucidate both conidial function and the karyological aspects of the generative reproductive cycle in Cladonia furcata as well as in most other lichenforming ascomycetes.

I am very grateful to Dr D. L. Hawskworth for critically reading and improving the English of this manuscript, and to $\mathrm{Mr}$ U. Jauch for his introduction to scanning electron microscopy and many valuable hints.

\section{REFERENCES}

Ahmadjian, V. (1964) Further studies on lichenized fungi. Bryologist 67: 87-98.

Ahmadjian, V. (1966) Artificial reestablishment of the lichen Cladonia cristatella. Science N. Y. 151: 199-201.

Ahmadjian, V. (1969) Lichen synthesis. Öst. bot. Z. 116: 306-311.

Anglesea, D., Veltkamp, C. \& Greenhalgh, G. N. (1982) The upper cortex of Parmelia saxatilis and other lichens. Lichenologist 14: 29-38.

Backus, M. P. (1939) The mechanism of conidial fertilization in Neurospora sitophila. Bull. Torrey bot. Club 66: 63-76.

Bauer, E. (1898) Zur Frage nach der Sexualität der Collemaceen. Ber. dtsch. bot. Ges. 16: 363-367.

Dodge, B. O. (1932) The non-sexual and the sexual functions of microconidia of Neurospora. Bull. Torrey bot. Cub 59: 347-360.

Esser, K. \& Kuenen, R. (1967) Genetik der Pilze. Berlin, Heidelberg, New York: Springer.

Glück, H. (1899) Entwurf zu einer vergleichenden Morphologie der Flechten-Spermogonien. Heidelberg: Carl Winters Universitätsbuchhandlung.

Hale, M. E. (1974) The biology of lichens. Second edition. London: Edward Arnold.

Henssen, A. (1963) Eine Revision der Flechtenfamilien Lichinaceae und Ephebaceae. Symb. bot. upsal. 18(1): $1-123$.

Henssen, A. \& Jahns, H. M. (1973 [1974]) Lichenes. Eine Einführung in die Flechtenkunde. Stuttgart: Thieme.

Honegger, R. (1978) Ascocarpontogenie, Ascusstruktur und -funktion bei Vertretern der Gattung Rhizocarpon. Ber. dtsch. bot. Ges. 91: 579-594.

Honegger, R. (1984) Ultrastructural studies on conidiomata, conidiophores and conidiogenous cells in 6 lichen-forming ascomycetes. Can. F. Bot. 62: (in press).

Jahns, H. M. (1970) Untersuchungen zur Entwicklungsgeschichte der Cladoniaceen unter besonderer Berücksichtigung des Podetienproblems. Nova Hedwigia 20: 1-177.

Jahns, H. M. (1973) The trichogynes of Pilophorus strumaticus. Bryologist 76: 414-418.

Jahns, H. M. \& Beltman, H. A. (1973) Variations in the ontogeny of fruiting bodies in the genus Cladonia and their taxonomic and phylogenetic significance. Lichenologist 5: 349-367.

Jahns, H. M., Herold, K. \& Beltman, H. A. (1978) Chronological sequence, synchronization and induction of the development of fruit bodies in Cladonia furcata var. furcata (Huds.) Schrad. Nova Hedwigia 30: 469-526. 
Johnson, G. Th. (1954) Ascogonia and spermatia of Stereocaulon. Mycologia 46: 339-345.

Letrouit-Galinou, M.-A. (1973) Sexual reproduction. In The Lichens. (V. Ahmadjian \& M. E. Hale, eds): 59-90. New York, London: Academic Press.

Lindsay, W. L. (1861) Memoir on the spermogones and pycnides of filamentous, fruticulose, and foliaceous lichens. Trans. $R$. Soc. Edinb. 22: 101-303.

Lindsay, W. L. (1872) Memoir on the spermogones and pycnides of crustaceous lichens. Trans. Linn. Soc. Lond. 28: 189-318.

Littlefield, L. J. \& Heath, M. C. (1979) Ultrastructure of rust fungi. New York, San Francisco, London: Academic Press.

Moreau, F. \& Moreau, C. (1928) Les phénomènes cytologiques de la reproduction chez les champignons des lichens. Le Botaniste 20: 1-67.

Moreau, F. \& Moreau, C. (1932) Sur un lichen du genre Stereocaulon Schreb., le Stereocaulon coralloides Fr. Bull. Soc. bot. Fr. 79: 508-515.

Nienburg, W. (1908) Beiträge zur Entwicklungsgeschichte einiger Flechtenapothecien. Flora, fena 98: $1-40$.

Stahl, E. (1877) Beiträge zur Entwicklungsgeschichte der Flechten. I. Ueber die geschlechtliche Fortpflanzung der Collemaceen. Leipzig: Arthur Felix.

Stevens, R. B. (1941) Morphology and ontogeny of Dermatocarpon aquaticum. Am. F. Bot. 28: 59-69.

Tulasne, L. R. (1852) Mémoire pour servir à l'histoire organographique et physiologique des lichens. Anm. sci. nat., Bot., sér. 3 17: 5-128, 153-249.

Vobis, G. (1977) Studies on the germination of lichen conidia. Lichenologist 9: 131-136.

Vobis, G. (1980) Bau und Entwicklung der Flechten-Pycnidien und ihrer Conidien. Bibltheca lichen. Vaduz 14: 1-141.

Wolff, G. (1905) Beiträge zur Entwicklungsgeschichte der Flechtenapothecien. Flora, fena 95: 31-57.

Accepted for publication 14 August 1983 
Downloaded from https:/www.cambridge.org/core. University of Basel Library, on 11 Jul 2017 at 09:04:53, subject to the Cambridge Core terms of use, available at https:/www.cambridge.org/core/terms. https://doi.org/10.1017/S0024282984000049 